\title{
Effects of dietary malic acid on growth, nutrient utilization and serum biochemical indices of Nile tilapia (Oreochromis niloticus) fingerlings
}

\author{
Magdy A. Soltan ${ }^{1}$, Mohamed S. Hassaan², Mahmoud R. El-Mahdy ${ }^{1}$ and Ahmed. A. Mahmoud ${ }^{1}$ \\ ${ }^{1}$ Faculty of Agriculture, Benha University, Egypt \\ ${ }^{2}$ Aquaculture Division, Fish Nutrition Research Laboratory, National Institute of Oceanography and Fisheries \\ (NIOF), Cairo, Egypt \\ Corresponding author: magdy.soltan@fagr.bu.edu.eg
}

\begin{abstract}
A 90 days feeding trial was conducted to investigate the effect of dietary supplementation with malic acid on growth, nutrient utilization and some hematological parameters of Nile tilapia (Oreochromis niloticus). Three isonitrogenous (300 $\mathrm{g} \mathrm{CP} \mathrm{kg}^{-1}$ ) and isocaloric (14.90 MJ gross energy kg $\mathrm{g}^{-1}$ ) diets were formulated. The control diet (D1) contained no added of malic acid. Two diets were supplemented with $0.5 \%$ (D2) and $1.0 \%$ (D3) malic acid. A set of 180 fish of $O$. niloticus L. mono-sex male fingerlings average initial weight of $7.56 \pm 0.06 \mathrm{~g}$ were randomly distributed into nine plastic tanks $\left(0.45 \mathrm{~m}^{3}\right.$ for each) representing the three treatments studied. Twenty fish were randomly stocked into each tank with three replications for each treatment. At the end of the feeding trial, $O$. niloticus offered the control diet showed lower growth and feed utilization than all those fed malic acid supplemented diets. Fish fed the diet D3 showed the highest body weight (BW) weight gain (WG), specific growth rate (SGR), feed intake (FI), and the best feed conversion ratio (FCR) and protein efficiency ratio (PER). Supplementation of malic acid $\left(5 \mathrm{~g}\right.$ or $\left.10 \mathrm{~g} \mathrm{~kg}^{-1}\right)$ increased hemoglobin $(\mathrm{Hb})$, hematocrit $(\mathrm{Htc})$ and red blood cell count (RBCs) of Nile tilapia, but white blood cells (WBCs) of did not significantly (P>0.05) affected by malic acid supplementation. The highest level of $\mathrm{Hb}$, Htc and RBC was recorded by fish fed $10 \mathrm{~g} \mathrm{~kg}^{-1}$. In the same direction supplementation the basal diet with $5 \mathrm{~g}$ or $10 \mathrm{~g} \mathrm{~kg}^{-1}$ malic acid significantly increased the levels of serum Albumin $\mathrm{u} / \mathrm{L}(\mathrm{P}<0.001)$, Globulin $(\mathrm{P}<0.05)$ and total protein $(\mathrm{P}<0.001)$. The present observations suggest that, growth and feed utilization of $O$. niloticus can be enhanced with a supplementation of $1.0 \%$ malic acid in the diet.
\end{abstract}

Key words: growth, nutrient, organic acid, Nile tilapia.

\section{Introduction}

Organic acids are an example of a group of additives which can play an important role in future in aquaculture diets. A number of studies, in cold-water species (Gislason et al., 1996) and tropical species (Ramli et al., 2005 and Petkam et al., 2008), indicated a broad range of organic acids, their salts or mixtures can improve growth, feed utilization and disease resistance in fish. Organic acids in animal feed were initially used in piglets to complement their limited capacity to maintain a low gastric $\mathrm{pH}$, which linked to problems with digestion (Easter, 1988). Antibiotic inhibit all microbial growth, whereas acidifiers are more selective in their activity (Cromwell, 1990). They can reduce harmful microorganisms and promote beneficial microflora colonization of the gastrointestinal tract (Mathew et al., 1991).

As reviewed by Baruah et al., (2008), the addition of organic acids in fish feeds may have many advantages; it may reduce the unwanted pathogenic microbial load in feed and the gut of fish; reduce toxic microbial metabolites by reducing the pathogenic microbes; enhance nutrient absorption due to proliferation of mucosal epithelium of the intestine; reduce the discharge of phosphorus in water thereby preventing aquatic pollution; reduce the risk of antibiotic residue in fish and prawns in those regions where antibiotics are used. Mineral absorption may also be enhanced due to more solubilization of $\mathrm{Ca}, \mathrm{P}$ and $\mathrm{Mg}$ etc from animal protein sources, especially in stomach-less fishes. Some organic acids especially citric, metacetonic and acetic, are also added to pellets for storage effects and/or the improvement of feed utilization (Kumar et al., 1997 and Sugiura et al., 1998).

Malic acid is a four-carbon dicarboxylic acid that occurs naturally in many fruit organic acids (it was first isolated from apples), and it is synthesized commercially (Sniffen et al., 2006). Malic acid has two stereoisomeric forms (L and D enantiomers), although only the L-isomer occurs naturally. This organic acid is used in foods as a flavor enhancer and for $\mathrm{pH}$ and microbial control, because it inhibits the growth of pathogenic bacteria and pathogenic fungi (Ricke, 2003). An exceptionally valuable nutritional property of this acid is that after oral administration, it stimulates the secretion of gastric juices and increases peristalsis. Small doses of malic acid have prebiotic properties, stimulating the development of nonpathogenic, acidophilic, and saprophytic bacteria, at higher doses, however, it can exhibit bacteriostatic and bactericidal properties (Salou et al., 1991). Generally, the present study was carried out to investigate the effect of graded levels of malic acid on growth performance, feed utilization, and some physiological aspects of Oreochromis niloticus.

\section{Materials and Methods}




\section{Fish and culture technique}

The present study was designed to investigate the effect of malic acid (dicarboxylic acid) on growth, feed utilization, hematological and biochemical blood parameters of Nile tilapia, O. niloticus. Experimental fish were obtained from National Institute of Oceanography and Fisheries (NIOF), Elqanater Elkhairia, Qalubia, Egypt. Fish were acclimated to the experimental conditions in four tanks for two weeks at the laboratory of fish nutrition, Faculty of Agriculture, Benha University. During the acclimation period, fish were fed a control diet (300 $\mathrm{g} \mathrm{kg}^{-1}$ crude protein) at a rate of $3 \%$ of biomass, which provided of equal rations at 09:00 am and 3:00 pm for 2 weeks to adapt fish to the artificial diet and conditions of the trail. After the acclimatization, the experimental fish were randomly distributed into the experimental plastic tanks $\left(0.45 \mathrm{~m}^{3}\right.$ for each) representing the three treatments studied. A set of 180 fish of $O$. niloticus L. mono-sex male fingerlings average initial weight of $7.56 \pm 0.06 \mathrm{~g}$ were used in this trail. Twenty fingerlings were randomly stocked into each tank with three replications for each treatment. Underground water was supplied to each tank housed within an artificially illuminated room. Each tank supplied with automatic heater (200 watt) to maintain the water temperature $\left(27-29^{\circ} \mathrm{C}\right)$. About onethird of water volume in each tank was daily replaced by aerated fresh water after removing the accumulated excreta. During the 90 -days experimental period, tilapia were hand-fed with the respective diet $3 \%$ of biomass twice daily at 09:00 am and 3:00 pm. Every two weeks, total fish was taken from each tank then weighted and the amount of feed was adjusted according to the changes in body weight throughout the experimental period.

\section{Water quality}

Water temperature was recorded daily at $1.00 \mathrm{pm}$ using a mercury thermometer. Dissolved oxygen (DO) was measured at 07.00 am using YSI model 56 oxygen meter (YSI Company, Yellow Springs Instrument, Yellow Springs, Ohio, USA). Total ammonia and nitrite were measured twice weekly using a DREL, 2000 spectrophotometer (Hash Company, Loveland, CO, USA). A pH was estimated on morning by using a $\mathrm{pH}$ meter (Orion $\mathrm{pH}$ meter, Abilene, Texas, USA). Water temperature ranged from 27.20 to $29.25^{\circ} \mathrm{C}$; dissolved oxygen (DO) ranged between 5.32 to $6.81 \mathrm{mg} / \mathrm{l} ; \mathrm{pH}$ values ranged between 8.04 to 8.30 and total ammonia ranged from 0.18 to $0.2 \mathrm{mg} / \mathrm{l}$ for the different treatments during the entire experimental period ( 90 days). All tested water quality criteria (temperature, $\mathrm{pH}$ value, $\mathrm{DO}$ and total ammonia) were suitable and within the acceptable limits for rearing Nile tilapia $O$. niloticus fingerlings (Boyd, 1990). These positive findings in water quality criteria related with good growth performance since there were no mortalities among all treatments. A photoperiod of 12-h light, 12-h dark (08:00-20:00 h) was used fluorescent ceiling lights supplied the illumination.

\section{Diet preparation}

Three isonitrogenous (293 $\mathrm{g} \mathrm{kg}^{-1}$ crude protein) and isocaloric (14.90 MJ kg-1 gross energy) experimental diets were formulated and analyzed (Table 1). The experimental diets were supplemented with short chain organic acid (malic acid) with 0,5 and $10 \mathrm{~g} \mathrm{~kg}^{-1}$ diet, and represented D1, D2 and D3, respectively. All dry ingredients of soybean meal, corn gluten, yellow corn, wheat bran and rice polishing were blended for 5 mins and thoroughly mixed with fish oil. The ingredients were mixed well and made into dry pellets using a laboratory pellet mill (California Pellet Mill, San Francisco, CA, USA). The pellets $\left(2-\mathrm{mm}\right.$ die) were dried for $4 \mathrm{~h}$ at $60^{\circ} \mathrm{C}$ and stored at $-20{ }^{\circ} \mathrm{C}$ until use.

\section{Growth performance and feed utilization parameters}

Records of live body weight $(\mathrm{g})$ and body length (cm) were measured in all fish for each tank and registered every 14 days (two weeks) during the experimental period. Growth performance parameters were measured by using the following equations: Weight gain $(\mathrm{WG})=$ final weight $(\mathrm{g})-$ initial weight $(\mathrm{g})$ Specific growth rate $(\mathrm{SGR})=\frac{\mathrm{LnW} 2-\mathrm{LnW} 1}{\mathrm{t}} \times 100$

Where: $\mathrm{Ln}=$ the natural $\log , \mathrm{W}_{1}=$ first fish weight, $\mathrm{W}_{2}=$ the following fish weight in grams and $t=$ period in days.

Feed conversion ratio $(\mathrm{FCR})=$ Feed ingested $(\mathrm{g}) /$ Weight gain $(\mathrm{g})$

Protein efficiency ratio $(\mathrm{PER})=$ Weight gain $(\mathrm{g}) /$ Protein ingested (g)

\section{Sample collection}

At the experiment termination, six fish were randomly selected from each treatment and anaesthetized with t-amyl alcohol to collect the blood sample. The remaining fish in the tank were maintained for subsequent analysis of gut microbial flora.

\section{Chemical analysis of experimental diets}

Dry matter, crude protein, crude lipid and ash contents were determined by the standard AOAC (1995). Dry matter was determined after drying the samples in an oven $\left(105^{\circ} \mathrm{C}\right)$ for $24 \mathrm{~h}$. Crude protein was determined by micro-Kjeldhal method, $\mathrm{N} \times 6.25$ (using Kjeltech auto analyzer, Model 1030, Tecator, Höganäs, Sweden) and crude fat by Soxhlet extraction with diethyl ether $\left(40-60^{\circ} \mathrm{C}\right)$. Ash was estimated by incineration at $550^{\circ} \mathrm{C}$ for $12 \mathrm{~h}$. Crude fiber content was determined using the method of Van Soest et al. (1991). Nitrogen-free extract was computed by taking the sum of values for crude protein, crude lipid, crude fiber, ash then subtracting this sum from 100 . 
Table 1. Ingredient and proximate composition of the experimental diets $\left(\mathrm{g} \mathrm{kg}^{-1}\right.$ dry matter)

\begin{tabular}{|c|c|c|c|}
\hline & D 1 & D 2 & D 3 \\
\hline Soybean meal (44\%) & 450 & 450 & 450 \\
\hline Corn gluten & 60 & 60 & 60 \\
\hline Yellow corn & 170 & 170 & 170 \\
\hline Wheat bran & 150 & 145 & 140 \\
\hline Rice polishing & 100 & 100 & 100 \\
\hline Fish oil & 40 & 40 & 40 \\
\hline Lysine & 5 & 5 & 5 \\
\hline Methionine & 5 & 5 & 5 \\
\hline Vit. \& Mine. $^{1}$ & 15 & 15 & 15 \\
\hline Vitamin C & 5 & 5 & 5 \\
\hline Malic acid & - & 5 & 10 \\
\hline \multicolumn{4}{|l|}{ Chemical analysis \% } \\
\hline Dry matter & 89.53 & 89.01 & 89.00 \\
\hline Protein & 29.32 & 29.26 & 29.18 \\
\hline Lipid & 6.06 & 6.04 & 6.02 \\
\hline Ash & 5.07 & 5.04 & 5.01 \\
\hline Fiber & 6.47 & 6.37 & 6.32 \\
\hline $\mathrm{NFE}^{2}$ & 53.08 & 53.29 & 53.47 \\
\hline ME energy $\left(\mathrm{kJ} \mathrm{g}^{-1} \text { feed }\right)^{3}$ & 14.87 & 14.89 & 14.88 \\
\hline
\end{tabular}

${ }^{1}$ Vitamin and mineral mix (mg or g/ Kg diet): MnSO4, 40 mg; Mg O, 10 mg; K2SO4, 40 mg; ZnCO3, 60 mg; KI, 0.4 mg; CuSO4, 12 $\mathrm{mg}$; Ferric citrate, $250 \mathrm{mg}$; Na2 SeO3, $0.24 \mathrm{mg}$; Co, $0.2 \mathrm{mg}$; retinol, $40000 \mathrm{IU}$; cholecalciferol, $4000 \mathrm{IU}$; $\alpha$-tocopherol acetate, $400 \mathrm{mg}$; menadione, $12 \mathrm{mg}$; thiamine, $30 \mathrm{mg}$; riboflavin, $40 \mathrm{mg}$; pyridoxine, $30 \mathrm{mg}$; cyanocobalamin, $80 \mathrm{mcg}$; nicotinic acid, $300 \mathrm{mg}$; folic acid, $10 \mathrm{mg}$; biotin, $3 \mathrm{mg}$; pantothenic acid, $100 \mathrm{mg}$; inositol, $500 \mathrm{mg}$.

${ }^{2} \mathrm{NFE}$ (Nitrogen free extract) $=100$ - (crude protein + lipid + ash + fibre content $)$.

${ }^{3}$ Metabolizable energy was calculated based on the standard physiological values of $18.8 \mathrm{~kJ} \mathrm{~g}^{-1}$ protein, $13.8 \mathrm{~kJ} \mathrm{~g}^{-1}$ carbohydrate, and $33.5 \mathrm{~kJ} \mathrm{~g}^{-1}$ lipid (Brett and Groves 1979).

\section{Determination of digestive enzymes activity}

Samples of intestine from each treatment were immediately homogenized in 10 volumes $\left(\mathrm{w} \mathrm{v}^{-1}\right)$ of icecold physiological saline solution and centrifuged at $5000 \mathrm{~g}$ for $15 \mathrm{~min}$ at $4^{\circ} \mathrm{C}$; then, the supernatant was stored for endogenous enzymes activity analysis (Furne et al., 2008). Chymotrypsin and trypsin activities were determined according to Deguara et al. (2003), and lipase activities were estimated according to the method described by Zamani et al. (2009).

\section{Blood sampling and hematological and biochemical indices}

At the end of the experiment, blood samples were collected from the caudal vein of fish in all treatments and were divided into two portions. The first portion was collected with the anticoagulant $10 \%$ Ethylenediaminetetraacetate (EDTA) to measure hematocrit $(\mathrm{Htc})$, haemoglobin $(\mathrm{Hb})$, red blood cells (RBCs) and white blood cells (WBCs). Htc was determined as described by Reitman and Frankel (1957), Hb was determined using haemoglobin kits which is a standardized procedure of the cyanomethemoglobin method, and the total count of WBCs was carried out by the indirect method (Martins et al., 2004). The second portion of the blood sample was allowed to clot at $4^{\circ} \mathrm{C}$ and centrifuged at $3,000 \mathrm{rpm}$ for $10 \mathrm{~min}$. The nonhemolyzed serum was collected and stored at $-20^{\circ} \mathrm{C}$ until use. Levels of serum aspartate aminotransferase (AST) and alanine aminotransferase (ALT) were measured according to the method described by Reitman and Frankel (1957), and serum creatinine was measured by calorimetric and enzymatic determine cation methods as described by Henry (1974). Total serum protein and albumin were determined according to Henry (1964) and Wotton and Freeman (1982), respectively. However, globulin was calculated by subtracting total albumin from protein according to Coles (1974).

\section{Statistical analysis}

All data were analyzed by using the software SAS, version 6.03 (Statistical Analysis System, SAS 1996). One-way analysis of variance (One-way ANOVA) was used to determine whether significant variation existed between the treatments. When overall differences were found, differences between means were tested by Duncan (1955) new multiple range test. Two-way ANOVA was used for analyzing the individual effects of malic acid and protease and the interaction between them. All differences were considered significant at $\mathrm{P}<0.05$ and the results are presented as means with pooled standard error of the mean).

\section{Results and Discussion}

\section{Growth performance and feed utilization}

Results presented in Table 2 showed that the differences in fish initial body weight among different treatments were insignificant indicating that, the 
experimental fish at the start of the experiment were randomly distributed. Supplementation of the basal diet with 5 or $10 \mathrm{~g}$ malic acid $\mathrm{kg}^{-1}$ significantly $(\mathrm{P}<0.05)$ increased the final fish body weight $(\mathrm{FBW})$ from 43.66 to 45.01 and $48.72 \mathrm{~g} /$ fish. In the same trend, weight gain $(\mathrm{WG})$ values significantly $(\mathrm{P}<0.05)$ increased from 36.04 to 37.48 and $41.10 \mathrm{~g} /$ fish when the basal diet supplemented with 5 or $10 \mathrm{~g}$ malic acid $\mathrm{kg}^{-1}$, respectively. The same trend was also recorded for specific growth rate. Fish fed the diets supplemented with 5 or $10 \mathrm{~g}$ malic acid $\mathrm{kg}^{-1}$ significantly $(\mathrm{P}<0.001)$ improved specific growth rate (SGR) from $2.08 \%$ (D1) to 2.13 (D2) and 2.23 day $^{-1}$ (D3). Nile tilapia fed the basal diet (D1) showed the lowest significant feed intake (62.66 g/fish), protein efficiency ratio (1.95) and the worst feed conversion ratio (1.74). Supplementation of the basal diet with 5 or $10 \mathrm{~g}$ malic acid $\mathrm{kg}^{-1}$ significantly $(\mathrm{P}<0.05)$ increased feed intake from 62.66 to 65.40 and 65.30 $\mathrm{g} /$ fish, respectively. Supplementation of the basal diet with $50 \mathrm{mg}$ protease did not alter the values of feed conversion ratio (FCR) and protein efficiency ratio (PER) while the highest level of malic acid $\left(10 \mathrm{~g} \mathrm{~kg}^{-1}\right)$ significantly improved FCR and PER.

Supplemented diets with 5 or $10 \mathrm{mg} \mathrm{kg}^{-1}$ malic acid in the current study significantly improved growth performance and feed utilization compared with the basal diet (D1). Similarly, it was found in a previous study that potassium-diformate $(0.2,0.3$, or $0.5 \%)$ significantly improved growth and FCR of $O$. niloticus (Ramli et al., 2005). In another study, Hassaan et al.
(2014) showed that $O$. niloticus fed a supplement of $1 \%$ Ca-lactate had significantly higher growth, increased feed intake, and improved FCR and PER than the control group. Compared with the negative control, $1.5 \%$ of Ca-formate, Ca-propionate, Ca-lactate, and citric acid blend resulted in a numerical increase in $\mathrm{WG}$ by $11 \%$ (Petkam et al., 2008). Rainbow trout (Oncorhynchus mykiss) fed 0.5 to 1.0 or $1.5 \%$ of formic acid+sorbic acid blend showed a significant improvement in BW, SGR, and FCR versus the control diet (De Wet 2005). Also, supplementation of sea bream (Pagrus major) diets with $1 \%$ of citric acid led to a significant improvement in fish growth (Hossain et al., 2007). In another study, Silva et al. (2016) found that the highest final weights were in white-leg shrimp (Litopenaeus vannamei) fed diets supplemented with fumarate, succinate, butyrate, and propionate, increasing 53\%, 46\%, 38\%, and 29\%, respectively compared with the control diet. Also, shrimp that were fed diets with fumarate digested more feed and had a feed conversion ratio $23 \%$ higher than the control group. The highest improvement in FCR and PER occurred when diets were supplemented with mixture of organic salts, and the lower FCR and PER was observed when fish were fed the control diet. These positive effects of diet acidification could be the results of the reduction of $\mathrm{pH}$ in the stomach by mixture of organic salts that would increase pepsin activity and consequently improve protein digestion (Mroz et al., 2000).

Table 2. Growth performance and feed utilization of Nile tilapia fed diets supplemented with

\begin{tabular}{|c|c|c|c|c|c|}
\hline & D1 & D2 & D3 & \multirow[t]{2}{*}{ MSE } & \multirow[t]{2}{*}{$\mathrm{P}$ values } \\
\hline & $0 \mathrm{~g} \mathrm{~kg}^{-1} \mathrm{MA}$ & $5 \mathrm{~g} \mathrm{~kg}^{-1} \mathrm{MA}$ & $10 \mathrm{~g} \mathrm{~kg}^{-1} \mathrm{MA}$ & & \\
\hline IBW $\left(\mathrm{g} \mathrm{fish}^{-1}\right)$ & 7.62 & 7.52 & 7.54 & 0.56 & 0.471 \\
\hline FBW $\left(\mathrm{g} \mathrm{fish}^{-1}\right)$ & 43.66 & 45.01 & 48.72 & 1.12 & 0.031 \\
\hline WG $\left(\mathrm{g} \mathrm{fish}^{-1}\right)$ & 36.04 & 37.48 & 41.10 & 1.01 & 0.041 \\
\hline SGR $\left(\%\right.$ day $\left.^{-1}\right)$ & 2.08 & 2.13 & 2.22 & 0.26 & 0.001 \\
\hline FI $\left(\mathrm{g} \mathrm{fish}^{-1}\right)$ & 62.66 & 65.40 & 65.30 & 1.12 & 0.013 \\
\hline FCR & 1.74 & 1.74 & 1.58 & 0.32 & 0.004 \\
\hline PER & 1.95 & 1.94 & 2.14 & 0.32 & 0.003 \\
\hline
\end{tabular}

Data are presented as means \pm standard mean error (SME) of triplicates.

Means followed by different letters in the same row are significantly different $(\mathrm{P}<0.05)$.

Hybrid tilapia $(O$. niloticus $\times O$. aureus) fed diets supplemented with $10 \mathrm{~g} \mathrm{~kg}^{-1}$ citric acid showed an increase in the activities of protease in the stomach by $29.6 \%$ but reduced the activities of protease in the intestine by $35.1 \%$ ( $\mathbf{L i}$ et al., 2009). The supplementation of diets with organic acids or their salts has been suggested to improve growth through improved digestion, absorption, and retention of a variety of nutrients and minerals. Organic acids also increase secretion of some enzymes such as proteases and modify digestive enzymatic activity and in vitro protein digestibility of white-leg shrimp, L. Vannamei (Silva et al., 2016). Acidification of fish diets alters digestive enzymes activity and consequently nutrient utilization (Silva et al., 2016). Soltan et al. (2017) investigate the effect of incorporation of graded levels of two organic acids (malic acid, oxalic acid) blend and two organic acid salts (calcium lactate, sodium acetate) blend in Nile tilapia (O. nloticus) diets. Fish fed the diet supplemented by $1 \%$ malic+oxalic acids blend showed the highest BW (25.45 g) and control group showed the lowest BW $(21.85 \mathrm{~g})$ also supplementation of the basal diet by each of malic+oxalic acids blend or Na-acetate+Ca-lactate blend significantly improved the final BW of Nile tilapia compared with the control groups.

\section{The activates of endogenous enzymes}

In the present study addition of malic acid ( $5 \mathrm{~g}$ or 10 $\mathrm{g} \mathrm{kg}^{-1}$ ) in Nile tilapia diets increased the activity of 
endogenous enzymes chymotrypsin, trypsin and lipase (Table 3). In this context, Li et al. (2009) reported that dietary citric acid $\left(10 \mathrm{~g} \mathrm{~kg}^{-1}\right)$ increased the protease activity in tilapia stomach. Moreover, activities of amylase in hepatopancreas and gut were found to be elevated due to changes in the gut $\mathrm{pH}$ induced by dietary citric acid. This subsequently affected the release of cholecystokinin and exocrine secretions of the pancreas. Similarly, Su et al. (2014) reported a significant increase in intestinal protease activity of white shrimp fed $2 \mathrm{~g} \mathrm{~kg}^{-}$ ${ }^{1}$ citric acid compared with the control group. However, no significant differences were observed for the amylase activity among the shrimp fed graded levels of citric acid. Castillo et al. (2014) showed that supplementation of potassium diformate (KDF) at $15 \mathrm{~g} \mathrm{~kg}^{-1}$ diet, especially citric acid, improved the growth performance in juvenile red drum, which they attributed in part to the enhanced activity of digestive enzymes. In this study, pepsinogen activity was found to be greater in the stomach of fish fed the acidified diets. Nevertheless, the researchers suggested that $\mathrm{pH}$ of the diets was not the only factor affecting the synthesis of pepsin, as it might also be influenced by other factors. Dietary citric acid and KDF also resulted in higher activities of trypsin, lipase and amylase in fish. It was hypothesized that gut acidification by organic acids may increase secretin concentration which ultimately stimulate the secretion of pancreatic enzymes. Silva et al. (2016) reported that, white shrimp showed an increase in trypsin and chymotrypsin activity when fed diet supplemented with sodium acetate or propionate, but the activities of these enzymes were decreased in shrimp fed the diets supplemented with sodium lactate or citrate. Sodium formate, butyrate, fumarate and succinate did not alter the activities of these digestive enzymes in shrimp.

Table 3. Activities of endogenous enzymes of Nile tilapia fed diets supplemented with graded levels of malic acid.

\begin{tabular}{llllll}
\hline & $\mathrm{D} 1$ & $\mathrm{D} 2$ & $\mathrm{D} 3$ & $\mathrm{MSE}$ & \multirow{2}{*}{$\mathrm{P}$ values } \\
\cline { 2 - 5 } & $0 \mathrm{~g} \mathrm{~kg}^{-1}$ & $5 \mathrm{~g} \mathrm{~kg}^{-1}$ & $10 \mathrm{~g} \mathrm{~kg}^{-1}$ & & \\
\hline Chymotrypsin $\left(\mathrm{U} \mathrm{g}^{-1}\right.$ tissue $)$ & 3.23 & 3.98 & 4.01 & 0.25 & 0.12 \\
\hline Trypsin $\left(\mathrm{U} \mathrm{g}^{-1}\right.$ tissue $)$ & 0.69 & 0.76 & 8.10 & 0.31 & 0.004 \\
\hline Lipase $\left(\mathrm{U} \mathrm{g}^{-1}\right.$ tissue $)$ & 718 & 811 & 850 & 9.36 & 0.005 \\
\hline
\end{tabular}

Data are presented as means \pm standard mean error (SME) of triplicates.

Means followed by different letters in the same row are significantly different $(\mathrm{P}<0.05)$.

\section{Hematological parameters of O. niloticus}

Results of Tables (4\&5) showed that, supplementation of malic acid (5 $\mathrm{g}$ or $10 \mathrm{~g} \mathrm{~kg}^{-1}$ ) increased hemoglobin $(\mathrm{Hb})$, hematocrit $(\mathrm{Htc})$ and red blood cell count (RBCs) of Nile tilapia, but white blood cells (WBCs) did not significantly $(\mathrm{P}>0.05)$ affected. The highest level of $\mathrm{Hb}$, Htc and RBC was recorded by fish fed $10 \mathrm{~g} \mathrm{~kg}^{-1}$.

Hematology is an important factor that could be considered for the fish diet quality assessment. Svobodová et al. (1991) reported that ichthohematology would be useful for the assessment of suitability of diets and feed mixtures, evaluation of fish conditions, determination of toxic effect of substances, as well as the diagnosis of disease. Ologhobo, (1992) reported that, one of the most common blood variables consistently influenced by diet is the hematocrit $(\mathrm{Htc})$ and hemoglobin $(\mathrm{Hb})$ levels. In the present study, addition of malic acid (5 $\mathrm{g}$ or $10 \mathrm{~g} \mathrm{~kg}^{-1}$ ) increased the levels of $\mathrm{Hb}$, Htc and RBCs of Nile tilapia, but white blood cells WBCs did not significantly $(\mathrm{P}>0.05)$ affected by malic acid supplementation. Khajepour and Hosseini (2012) showed that acidifying the diet of Juvenile Beluga (Huso huso) by adding 3\% citric acid significantly increased $(\mathrm{P}<0.05) \mathrm{Hb}$ and $\mathrm{Htc}$ values in Beluga. Hassaan et al. (2014) reported that diet supplemented with Ca-propionate or Ca-lactate at the different level $(0.5,1.0$ or 1.5$)$ significantly $(\mathrm{P}<0.05)$ increased hematocrit $(\mathrm{Htc})$ and hemoglobin $(\mathrm{Hb})$ values of Nile tilapia compared with fish fed the control diet and supplementation the experimental diets with $1.0 \%$ of each salt (Ca-propionate or Ca-lactate) released the highest $\mathrm{Htc}$ or $\mathrm{Hb}$ value compared with the other treatments. In another study, Hassaan et al. (2017) reported that Htc, $\mathrm{Hb}$, red blood cell and white blood cell values of Nile tilapia fed diet supplemented with malic acid were significantly higher than control diet. Fortunately, the increase in hematological indices in the present study for fish fed the diet supplemented with malic acid increase the oxygen carrying capacity in the blood.

Table 4. Hematological parameters of Nile tilapia fed diets supplemented with graded levels of malic acid.

\begin{tabular}{llllll} 
& $\mathrm{D} 1$ & $\mathrm{D} 2$ & $\mathrm{D} 3$ & $\mathrm{MSE}$ & P values \\
\cline { 2 - 5 } & $0 \mathrm{~g} \mathrm{~kg}^{-1}$ & $5 \mathrm{~g} \mathrm{~kg}^{-1}$ & $10 \mathrm{~g} \mathrm{~kg}^{-1}$ & & \\
\hline $\mathrm{Hb}(\mathrm{g} / \mathrm{dl})$ & 13.25 & 14.63 & 15.98 & 0.98 & 0.001 \\
\hline $\mathrm{Htc}(\%)$ & 22.15 & 24.80 & 26.36 & 0.23 & 0.002 \\
\hline $\mathrm{RBCs} \times 10^{3}$ & 1.80 & 2.25 & 2.50 & 0.03 & 0.011 \\
\hline $\mathrm{WBCs} \times 10^{6}$ & 35.60 & 35.90 & 36.20 & 1.26 & 0.420 \\
\hline
\end{tabular}

Data are presented as means \pm standard mean error (SME) of triplicates.

Means followed by different letters in the same row are significantly different $(\mathrm{P}<0.05)$. 
Liver function and biochemical parameters

Alanine aminotransferase (ALT), aspartate aminotransferase (AST) and alkaline phosphatase (ALP) enzymes an important liver enzymes indicator for liver health and function through controlling transferring amino group function of alpha-amino acids to alpha-keto acids. Large amount of ALT and AST are released into animal blood, mostly during liver cell damage (Kumar et al., 2011). Increases in proteinogram levels are thought to be associated with a stronger innate response in fish (Jha et al., 2007). Generally, the present study showed a significant reduction in the levels of ALT and AST due to acidification of the experimental diets with malic acid and this may be due to improvement in general health of fish fed acidified diets (Table 5).

Our results showed a positive significant effect of acidification with malic acid of $O$. nilotics diets on serum total protein, albumin and globulin (Table 6). Globulin level is very often used as an indicator of immune responses and a source of antibody production. Baruah et al. (2007) also indicated a significant increase in total serum protein of Rohu $(L$. Rohita) when fed diet supplemented with citric acid. Nile tilapia fed diets containing malic acid exhibited a significant decrease in transaminases ALT and AST activity as well as improved values of total protein, albumin and globulin compared with fish fed the control diet (Hassaan et al., 2017).

Table 5. Liver enzymes activates of Nile tilapia fed diets supplemented with graded levels of malic acid.

\begin{tabular}{llllll}
\hline & $\mathrm{D} 1$ & $\mathrm{D} 2$ & $\mathrm{D} 3$ & \multirow{2}{*}{ MSE } & P values \\
\cline { 2 - 4 } & $0 \mathrm{~g} \mathrm{~kg}^{-1}$ & $5 \mathrm{~g} \mathrm{~kg}^{-1}$ & $10 \mathrm{~g} \mathrm{~kg}^{-1}$ & & \\
\hline ALT $(\mathrm{u} / \mathrm{L})$ & 22.15 & 20.80 & 20.12 & 0.98 & 0.012 \\
\hline AST $(\mathrm{u} / \mathrm{L})$ & 15.16 & 13.12 & 12.90 & 0.68 & 0.001 \\
\hline ALP $(\mathrm{u} / \mathrm{L})$ & 139.20 & 132.33 & 130.10 & 2.68 & 0.002 \\
\hline
\end{tabular}

Data are presented as means \pm standard mean error (SME) of triplicates.

Means followed by different letters in the same row are significantly different $(\mathrm{P}<0.05)$.

Table 6. Total protein, albumin ande globulin of Nile tilapia fed diets supplemented with graded levels of malic acid.

\begin{tabular}{llllll}
\hline & $\mathrm{D} 1$ & $\mathrm{D} 2$ & $\mathrm{D} 3$ & MSE & P values \\
\cline { 2 - 4 } & $0 \mathrm{~g} \mathrm{~kg}^{-1}$ & $5 \mathrm{~g} \mathrm{~kg}^{-1}$ & $10 \mathrm{~g} \mathrm{~kg}^{-1}$ & & \\
\hline Total protein u/L & 3.79 & 4.60 & 5.21 & 0.36 & 0.001 \\
\hline Albumin u/L & 1.78 & 2.12 & 2.56 & 0.25 & 0.032 \\
\hline Globulin u/L & 2.01 & 2.58 & 2.56 & 0.12 & 0.023 \\
\hline
\end{tabular}

Data are presented as means \pm standard mean error (SME) of triplicates.

Means followed by different letters in the same row are significantly different $(\mathrm{P}<0.05)$.

\section{References}

AOAC (1995). Official Methods of Analysis of the Association Official Analytical Chemists, vol. $1,16^{\text {th }}$ ed. AOAC International, Arlington, USA.

Baruah, K., Norouzitallab, P., Debnath, D., Pal, A.K. and Sahu, N.P. (2008). Organic acids as non-antibiotic nutraceuticals in fish and prawn feed. Aquaculture Health International. March 2008.

Baruah, K., Sahu, N.P., Pal, A.K., Debnath, D. and Yengkokpam, S. (2007). Interactions of dietary microbial phytase, citric acid and crude protein level on mineral utilization by Rohu, Labeo rohita (Hamilton), juveniles. J. World Aquac.Soc., 38: 238-249.

Boyd, C.E. (1990). Water quality in ponds for aquaculture. Alabama Agricultural Experiment Station, Auburn university. Alabama P462.

Brett J.R. and Groves T.D. (1979). Physiological energetics. In: Fish Physiology, Vol. 8 (ed. By W.S. Hoar, D.J. Randall and J.R. Brett), pp.280344. Academic Press, London, UK.
Castillo, S., Rosales, M., Pohlenz, C., and Gatlin III, D.M. (2014). Effects of organic acids on growth performance and digestive enzyme activities of juvenile red drum Sciaenops ocellatus. Aquaculture, 433:6-12.

Coles, E.H. (1974). Plasma proteins. In: Veterinary clinical pathology, 2nd edition. W.B. Saunders Co., Philadelphia, Pennsylvania, USA, pp. 558560.

Cromwell, G.L. (1990). Antimicrobial agents. In: Swine Nutrition. Edited by E. R. Miller, D. E. Uiirey and A. J. Lewis. Butterworth-Heiemann. Boston, MA, USA pp. 297-313.

Deguara, S., Jauncey, K. and Agius, C. (2003). Enzyme activities and $\mathrm{pH}$ variations in the digestive tract of gilthead sea bream. J. Fish Biol., 62, 1033-1043

de Wet, L. (2005). Organic acids as performance enhancers. Aqua Feeds: Formulation and Beyond 2:12-14.

Duncan, M.B. (1955). Multiple ranges and multiple F-tests. Biometrics, 11: 1-42.

Easter, R.A. (1988). Acidification of diets for pigs. In: Recent Advances in Animal Nutrition. Edited 
by W. Haresign and D. J. A. Cole. Butterworth, London, UK. PP. 61-72.

Furne, M., García-Gallego, M., Hidalgo, M. C., Morales, A.E., Domezain, A., Domezain, J. and Sanz, A. (2008). Effect of starvation and refeeding on digestive enzyme activities in sturgeon (Acipenser naccarii) and trout (Oncorhynchus mykiss). Comp. Biochem. Physiol., 149:420-425.

Gislason, G., Olsen, R. E. and Ringø, E. (1996): Comparative effects of dietary Na-lactate on Arctic char, Salvelinus alpinus L., and Atlantic salmon, Salmo salar L. Aquaculture Research, 27:429-35.

Hassaan, M.S., Soltan, M.A., Jarmolowicz, S., and Abdo, H.S. (2017). Combined effects of dietary malic acid and Bacillus subtilis on growth, gut microbiota and blood parameters of Nile tilapia (Oreochromis niloticus). Aquaculture Nutrition, 23(2). DOI:10.1111/anu.12536.

Hassaan, M.S., Wafa, M.A., Soltan, M.A., Goda, A.S., and Mogheth, N.M. (2014). Effect of dietary organic salts on growth, nutrient digestibility, mineral absorption and some biochemical indices of Nile tilapia; Oreochromis niloticus L. fingerlings. World Applied Science Journal, 29(1):47-55.

Henry, R.J. (1964). Colorimetric determination of total protein. Clinical Chemistry. Harper and Row Publ., New York, USA, p. 181.

Henry, R.J. (1974). Clinical Chemistry Principles and Techniques, $2^{\text {nd }}$ ed. Harper and Row. Publ, New York, p. 525.

Hossain, M.A., Pandey, A. and Satoh, S. (2007). Effects of organic acids on growth and phosphorus utilization in red sea bream Paugrs major. Fisheries Science 73:1309-1317.

Jha, A.K., Pal, A., Sahu, N., Kumar, S., and Mukherjee, S. (2007). Haemato-immunological responses to dietary yeast RNA, $\omega-3$ fatty acid and $\beta$-carotene in Catla catla juveniles. Fish and Shellfish Immunology, 23:917-927.

Khajepour, F. and Hosseini, S.A. (2012). Calcium and 38: 109-120. phosphorus status in juvenile beluga (Huso huso) fed citric acid-supplemented diets. Aquaculture Research, 43:407-411.

Kumar, D., Kaller, H., Bhaskar, N., Bhandary, M. H., Antony, M. J., Raju, C.V. and Biradar, V.M. (1997). Lipid oxidation and subsequent browning in salted-dried mackerel (Rastrelliger kanagurta Cuvier). Ind. J. Fish., 44:377-385.

Kumar, V. H., Makkar, P.S., Devappa, R.K. and Becke, K. (2011). Isolation of phytate from Jatropha curcas kernel meal and effects of isolated phytate on growth, digestive physiology and metabolic changes in Nile tilapia (Oreochromis niloticus L.). Food and Chemical Toxicology, 49:2144-2156.

Li, J.S., Li, J.L. and Wu, T.T. (2009). Effects of nonstarch polysaccharides enzyme, phytase and citric acid on activities of endogenous digestive enzymes of tilapia (Oreochromis niloticus $\times$ Oreochromis aureus). Aquaculture Nutrition, 15:415-420.

Martins, M.L., Nomura, D.T., Myiazaki, D., Pilarsky, F., Ribeiro, K., and Castro, M.P. (2004). Physiological and haematological response of Oreochromis niloticus (Osteichthyes: Cichlidae) exposed to single and consecutive stress of capture. Acta. Sci. Anim. Sci., 26:449456.

Mathew, A.G., Sutton, A.L., Scheidt, A.B., Forsyth, D.M., Patterson, J.A. and Kelly, D.T. (1991). Effects of a propionic acid containing feed additive on performance and intestinal microbial fermentation of the weanling pigs. In: Proceedings Sixth International Symposium on the Digestive Physiology in Pigs. PUDOC. Wageningen, The Netherlands. Pp. 464-469.

Mroz, Z., Jonbloed, A. W., Partanen, K. H., Vreman, K., Kemme, P. A and Kogut. J. (2000). The effects of calcium benzoate in diets with or without organic acids on dietary buffering capacity, apparent digestibility, retention of nutrients, and manure characteristics in swine. $\mathrm{J}$. Anim. Sci., 78:2622-2632. doi: $10.2527 / 2000.78102622 x$.

Ologhobo, A.D. (1992). Nutritive values of some tropical (West African) legumes for poultry. Journal Applied Animal Research, 2: 93-104.

Petkam, R., Lückstädt, C., Nittayachit, P., Sadao, S. and Encarnacao, P. (2008). Evaluation of a dietary organic acid blend on tilapia Oreochromis niloticus growth performance. Abstract CD-Rom, World Aquaculture Society, 19-23 May 2008, Busan, Korea.

Ramli, N., Heindl, U. and Sunanto, S. (2005). Effect of potassium-diformate on growth performance of tilapia challenged with Vibrio anguillarum. Abstract CD-Rom World Aquaculture Society, 913 May 2005; Bali, Indonesia.

Reitman, S., and Frankel, S. (1957): Colorimetric determination of glutamic oxaloacetic and glutamic pyruvic transaminases. J. Clinic Pathol., 28:56-59.

Ricke, S. (2003). Perspectives on the use of organic acids and short chain fatty acids as antimicrobials. Poult. Sci.,82:632-639.

Salou, P., Leroy, M., Goma, G. and Pareilleux, A. (1991). Influence of $\mathrm{pH}$ and malate-glucose ratio on the growth kinetics of Leuconostoc oenos. Appl. Microbiol. Biot.,36: 87-91.

Silva, B.C., Nolasco-Soria, H., Magallón Barajas, F., Civera-Cerecedo, R. Casillas- Hernández, R. and Seiffert, W. (2016): Improved digestion and initial performance of whiteleg shrimp using organic salt supplements. Aquaculture Nutrition, 22:997-1005. doi:10.1111/anu.2016.22.issue-5.

Sniffen, C., Ballard, C., Carter, M., Cotanch, K., Dann, H., Grant, R., Mandebvu, P., Suekawa, M. and Martin, S.A.(2006). Effects of malic acid 
on microbial efficiency and metabolism in continuous culture of rumen contents and on performance of mid-lactation dairy cows. Anim. Feed Sci. Technol., 127:13-31.

Soltan, M.A., Hassaan, M.S. and Meshrf, R.N. (2017). Response of Nile tilapia (Oreochromis niloticus) to diet acidification: Effect on Growth performance and feed utilization. Journal of Applied Aquaculture, 1-13.

Statistical Analysis System (SAS) (1996). SAS Procedure Guide version 6.12 Ed. SAS Institute Inc., Cary, NC, USA.

Su, X., Li, X., Leng, X., Tan, C., Liu, B. and Chai, X. (2014). The improvement of growth, digestive enzyme activity and disease resistance of white shrimp by the dietary citric acid. Aquaculture International 22:1823-1835.

Sugiura, S.H., Dong, F.M. and Hardy, R.W. (1998). Effects of dietary supplements on the availability of minerals in fish meal; preliminary observations. Aquaculture, 160:283-303.

Svobodová, Z., Fravda, D. and Palakova, J. (1991). Unified methods of haemato logical examination of fish. Research Institute of Fish Culture and Hydrobiology, VURH Vodnany, Edice Metodik, Czechoslovakia.

Van Soest, P.v., Robertson, J. and Lewis, B. (1991). Methods for dietary fiber, neutral detergent fiber, and nonstarch polysaccharides in relation to animal nutrition. J. Dairy Sci.,74:3583-3597.

Wotton, I. D. and Freeman, H. (1982). Micro analysis in Medical Biochemistry. Churchill, New York, USA.

Zamani, A., Hajimoradloo, A., Madani, R. and Farhangi, M. (2009). Assessment of digestive enzymes activity during the fry development of the endangered Caspian brown trout Salmo caspius. Journal of Fish Biology, 75(4):932-937. 